\title{
MTNIIO ACTIVIIIES
}

FIRSI DIVISION - Most of the company exploration parties are st1Il bard at it in this end other Hivistons. Several arliling projects are otill in progress, Bowe bave been completed.

The Kuwran fron ore pllot plant turned out its quota of concentrate for the sumer and ceased operations some time ago. Churn drilling is still continuing on the plecer portion of the deposit. The worl is being done by U. S. Steel.

The Yt. Andrew Mining Company of Vancouver, B. C. Is drilling the Mt. Andrew Iron-copper deposit on Kegann Peningula of Prince of Walea Island.

Tho Southesstern Mining and Exploration Coupany of Juneell 18 artiling their uranium proopect above William Henry Bay on Iynn Canal with DMEA asalatance.

The Kenarlck Bay Mining Company is mining the Ross-Adams uranium lode pretty much on achedule. The roed was corpleted, and the trucks are now bauline down the mountein from the open p1t operation at the rate of about 400 tons per day and stockpling on the beach. The otockplle presently amounts to orer 8,000 tons. Shipment will be by berge when a larger stockpjile has accumulated.

gaCOAD DIVISION - Placer operators have been hard htt for water this year in this DIVision and other placer districts throughout Alaska. The abnormally dry oumer hes held some miners down to a few minutes' slulcing a day, or even less. In somo of the lerger operations, It has been difficult to keep dredge pond levels up.

Kennecott's exploration division, Bear Creek Minlag Company, is contimuIng 1ts exploration on the Ruby Creek copper prospect north of the Kobuk River. Tis: prospect was formorly belng developed by Rlny Berg and Jack Bullock of Chitine and Kotzebue, respectively. Dehl Creek Mining Company $1 \mathrm{~s}$ building a roed to the proppect for Beer Creek Instead of miating this seeson.

IHIRD DIVISION - A mall shipment of metallurgical trade chromite from the fled Mountain area was made by Bill Lyons and Assoclates at Seldovia. The ore vas produced from a concentration of surface material.

Our personnel in Anchorage have not1ced a very decided increese in interest in plecer mining this sumer. We hope this will lesd to more operations.

FOURLA DIVISION - Increased activity amoag the several cinnaber prospects of the lower Kuskakin, Bek River, and Marsh Mountain (Third Division) Indicates that there may vell be two or three more mercury producers in the near future if the price holds up. The mercury belt 18 a large one and several compantes and individuala are 
GOLD INTEREST REVIVTNG?

The Canadian mining newspapers have been carrylng items and edttorials for the past few weeks on a very luteresting trend. Interest in gold mining is on the increase in Canade. It if continues, the Canadian optimism should spread to the U.S. There are probably two or three things that have atarted this trend. One was a sigmificant statement by the U.S. Undersecretary of the Treasury, Randolph Burgess, that this country should get back on the gold standard. This is quitse a statement for one that high in an administration that has repeatedly come out against any moves toward a gold standard. . Then there were announcements from a few eastern Canada gold mined that profits were up in splte of increased costs. Some of the gold stocks on the Toronto exchange actually came up on one or two occesions while other metal stocks were dropping because of the lowering base metal prices. More inquiries to the authorities on gold are being recelved, and generally speaking, a Budiden widespread interest in gold seems to have sprung up over there. One report was recelved of capital looking for a good lale gold mine just to hang on to unt1l times were better for gold. Some "experts" flgure that forelgn countrles holding U.S. paper currency are beginning to worry about a shortage of gold at Fort knox to cover 1t, eud are thinking that they should trade the paper for gold before the paper gets deflated any further than it already is. Whatever the reasons may be for this new trend, we are glad to see it and hope it continues. THme will tell.

\section{NEW USGS PUBLICATIONS}

A very welcome addition to USGS maps is their new "Geologic kig of Alagka." It $1 \mathrm{~s}$ a big Improvement from the last overall geologic map published 1n 1939, and is In such demand that the supply at the Juneau USGS office is sold out alraady. Prospectors and exploretion farties will flud it to be an almost essential 1tem. It can be obtained from the usual USGS map supply sources for the price of $\$ 2.00$ The scale Is 40 miles to the inch.

Another welcome USGS map is the open file "Preliminary geologic mep of part of the Bokan Mountaln uranium-thorlum area, Alaska" by E. M. Mackevett, JI. This map is accompanied by a short text and is the result of work done last year on Bokan Mountein in the vicinity of the now producing Ross-Adams uranium lode on Prince of Wales Islend. It shows the geologlc setting of that lode and other radioactive prospects in a 15-square-mile area. This map can be consulted at the various USGS offices in Aleska and et the Juneer and Ketchikan TDM offices. Reproductions WII be made at private expense if the USGS is contacted at 4 Homewood Place, Menlo Park, California. Mr. Mackevett's work in the Bokan area is continuing.

A new builetin has been published entitled "Mungsten deposits in the Fairbanks district, Alsokis." Its number 18 1024-I. It deals with the geology of those deposits and suggests that undiscovered lodes of scheelite mey yet extst in that district. The bulletin can be consulted in Alaslia in all offices of the USGS and TDM. It can be purchased from the Superintendent of Documents, Government Printing offlce, Washington 25, D. C. for \$l.00.

\section{CORRECTION}

Some of our readers have accused us of trylng to short-change the Territory. in our report last month on the new percentage of oll and gas revenues that Alaska -111 recelve, we stated that the new figure is $52-1 / 2 \%$. We neglected to add that 
this is in additfon to the $37-1 / 2 \%$ that we were alresdy recelving, which will now alve $u$ a totel of $90 \%$ of the revenues from royalties, rentals, etc. from oil and 18 production. Never let 1t be sald that we are trylng to cut of any revenue to Alaskb whlch we hope will some day Ilghten our lncome tax.

\section{AMRONIUM HYPOPEOSPHITE DITNERAL TESTING}

Our assayer in Ketchlkan, Mr. Ralph Pray, has given us the procedure for a new (to us) and almple method of testing for nine elements: chromium, cobalt, columblum, manganese, molybdenum, titenium, tungsten, uranium, and vanadium. Four ounces of the reagent, ammonium hypophosphite, evaliable in many chemical and drus houses, will ouffice to fuse several hundred samples. Containers in which to make the test should be porcelain crucibles of the $f_{0}(0)$ size, sold by laboratory equipment dealers. These cruclbles may be wasbed with water aiter use.

The sarple to be tested is crushed to a powder w1th a hanmer or mortar and pestle, and an amount taken equal to no nore than the phosphorus tip on the head of a wooden match. After plecing as amount of armontum hypophosphite equal to the size of a fee in the cructble, the sample is sprinkled over the reagent and the cruclble placed over a hot plame. CAUTION: Avold breathlag the fumes glven off by the beating, and do not run tibis test in an enclosed room. Reat the material until it becomes well fused, then cool and note the color of the fusion.

Green fusion indicates chromium, uranim, or vanadium. Add a fev drops . of hydrogen peroxide, reheat and cool. If the fuston is smoky grey, it contains chromiun; if rose plak, vanadium; and 1f still green, chronium or uranium. In the latter case, reheat, and if fuston is st1ll green at red heat, uranium is proven. If not, then chromium is indicated.

Blue fusion indicates tungsten or titanium. To test for tungsten, add ten to fifteen drops of water. If blue turns to violet in fifteen minutes, tungsten is proven. Th1s test is sensitive to less tban $0.1 \%$ tungsten, and a deeper vlolet indicates a blgher grade. To test for titaniun, add about ten drops of hydrogen peroxide to a second fueion. A yellow" (low grade) to red-orange (hlgh grade) color Indicates titanium. Small anounts of titanium in iron will glve a positive test with the hydrogen peroxdde.

P1nk fusion that was blue when hot indicates cobalt. If blue again when reheated, cobelt is proven.

Colorless thision may inalcete nan ganese, molybdeaum, or columblum. Add a few drops of attric acld and boll until dry. Rose-purple color just as acid bolls away indicates manganese. This is an extremely gensitive test which will show a manganese contant of less than $0.5 \%$. If the color is a falat greenlsh-blue arter the acid has bolled away, molybdenum is inalcated. Add jo to 15 drops of water. Color w11 change to yellow $1 f$ molybdenum is present. To test for columbium, add hydrochloric acid to a becond fusion, heat to boil, and add small plece of tin while the mixture is hot. A blue color lndicates columbium.

The colors of the teats are hest when viewed right after the fuslong have oooled, unless otherwise noted. However, most of the colors will remain distinctive for several hours. The tests should flist be made with ores or chemicals known to contaln the element sought so that the prospector will be fenjliar with the expected

oults before testing the unknow samples. Mr. Pray states that he will be glad to

sist anyone in obtalning supplies for the tests or answer questions on them. His address is TDM Assay Offlce, Box 1408,Ketchikan, Alaska. This service will be free of charge, the same as all other services of' the TDM. 
Since publishing our item on the DMEA move to spokane last month, we have been informed that DMEA does have a representative in Alaska, part time. It is $\mathrm{Ed}$ Mackevett, USGS geologf.6t who 15 a.? elsewhere in thlis 1ssue. Ed advises that he will answer all mail on the subject addressed to 204 Austin Tower, Ketchikar, and wIll arrange to meet anyone in Ketchikan until shortly after Octcber 1 when he will. go south for the wiater. He plans no more trips north to the Interlor this yeer, but will return next sumer. In the meantime, the Spokene address given last month is still ir effect.

\section{CONGMESSIONAL NEIS}

The tidelands bill to transfer title of tidelands within surveyed townsites to Alegka has been passed by both houses and now awalts the President's Bignature.

Senator Blble's bill to allow geophyslcel work to be applied as assesment work hes pessed the Senate and is now in the House Interlor Commitee.

The bill to allow leasing of tide and subroerged lands for ofl and gas exploration pessed the Kouse, but seems doomed to stay in the Senate Interior Committee until next year. The cormittee is reported to have repeatedly delayed action on it without explanation. If passed, it will eventually mean more development and revenue to Alasika.

On August 20, the Senate pessed with mivor arenoments a Rouse bill to provlde that milltary withdrawals of over 5,000 ecres for one Defense Department facility can be made ouly by Act of Congress. The bill is expected to go to the President for signature soon.

\section{E. AND M. J. METAI, MARKET ERICTS}

\begin{tabular}{|c|c|c|c|}
\hline & $\begin{array}{l}\text { AUE. 22, } \\
1957\end{array}$ & $\begin{array}{l}\text { Month } \\
\text { Ago }\end{array}$ & $\begin{array}{l}\text { Year } \\
\text { Ago }\end{array}$ \\
\hline $\begin{array}{l}\text { Copper, per Ib. } \\
\text { Lead, per lb. } \\
\text { Zinc, per lb. } \\
\text { Tin, per Ib. } \\
\text { Quickillver, per Ilask } \\
\text { Silver, foreign, New York } \\
\text { Silver, domestic, per oz. } \\
\text { Nickel, per Ib. } \\
\text { Molybdenum, per Ib., in con. } \\
\text { Platimum, per oz. } \\
\text { Titanium ore (IImenite) }\end{array}$ & $\begin{array}{l}28.0 \phi \\
14 \phi \\
10 \% \\
94.16 \\
\$ 251-253 \\
90.96 \\
90-1 / 2 \phi \\
746 \\
\$ 1.18 \\
\$ 81-87\end{array}$ & $\begin{array}{l}28.76 \\
144 \\
104 \\
964 \\
\$ 255-257 \\
90.24 \\
90.1 / 26 \\
748 \\
\$ 1.18 \\
\$ 89-95\end{array}$ & $\begin{array}{l}39.7 \phi \\
16 \phi \\
13-1 / 2 \phi \\
99-1 / 4 \phi \\
\$ 255-257 \\
90-3 / 4 \phi \\
90-1 / 2 \phi \\
64-1 / 2 \phi \\
\$ 1.18 \\
\$ 103-108\end{array}$ \\
\hline $\begin{array}{l}\text { per ton } \\
\text { *Tungsten ore per unit } \\
\text { HChrome ore }(48 \%, 3 \text { to } 1 \text { ratio })\end{array}$ & $\begin{array}{l}\$ 26.25-30.00 \\
\$ 55.00\end{array}$ & $\begin{array}{l}\$ 26.25-30.00 \\
\$ 55.00\end{array}$ & $\begin{array}{l}\$ 26.25 \\
\$ 63.00\end{array}$ \\
\hline $\begin{array}{l}\text { per ton } \\
\text { *GSA tungsten purchasing preser } \\
\text { *GI3.50-\$14.00, dependine on } \\
\text { *Gatanteed stocipile price }\end{array}$ & $\begin{array}{l}\text { \$I15.00 } \\
\text { atly guspended. } \\
\text { grade. }\end{array}$ & $\begin{array}{l}\$ 115.00 \\
\text { Forelgn import }\end{array}$ & $\begin{array}{l}\$ 115.00 \\
\text { price }\end{array}$ \\
\hline
\end{tabular}

